\title{
A Study of Problems of Teacher Educator in Self-Finance College of Education During COVID-19 Pandemic Situation
}

\author{
Bhalchandra Bhave
}

Shikshan Prasarak Sanstha's, College of Education Sangamner, Dist. Ahmednagar, Maharashtra, India

Corresponding author: bhaveb@gmail.com

Received: $12-03-2020$

Revised: 17-06-2020

Accepted: 24-07-2020

\begin{abstract}
A main objective of the present study was to know the problems of Teacher educator of Self-Finance college of Education during COVID-19 Pandemic situation. COVID-19 pandemic seems to be having a huge impact on Indian education system. The study was taken following objectives: 1 . To study the Academic problems of Teacher educator of Self-Finance college of Education during COVID-19 Pandemic situation. 2. To study the Financial problems of Teacher educator of Self-Finance college of Education during COVID-19 Pandemic situation. 3. To study of problems regarding admission procedure of SelfFinance college of Education during COVID-19 Pandemic situation. 4. To suggest expected changes in Teacher Education. Sample consisted 100 teacher educators. Problem Scale (PS) was developed by investigators themselves. Survey type research method was used. Data were collected from sample by Rating Scale. Collected data were analyzed by statistical technique percentage and frequency. Finding revealed that many problems are faced by teacher educator of Self-Finance college of education during COVID-19 Pandemic situation.
\end{abstract}

Keywords: Non grantable, Self-Finance, COVID, Pandemic

The COVID-19 pandemic in India is part of the world stress pandemic of corona virus disease caused SARS-CoV-2. The first case of COVID-19 in India was reported on $30^{\text {th }}$ January 2020. India currently has the largest number of active cases in Asia and has the third highest number of confirmed cases in the world After the USA and Brazil, India has the third highest cases in the world. Active Cases have continued to increase persistently. On 22 March, India observed a 14-hour voluntary public curfew. It was followed by mandatory lockdowns in COVID-19 hotspots and all major cities. Further, on 24 March, the Prime Minister ordered a nationwide lockdown for 21 days, affecting the entire 1.3 billion population of India. On $14^{\text {th }}$ April, the Government extended the nationwide lockdown till $3^{\text {rd }}$ May which was followed by two-week extensions starting 3 and 17 May with substantial relaxations. From 1 June, the Government has started "unlocking" the country (barring "containment zones") in three phases. COVID-19 pandemic seems to be having a huge impact on Indian education system. Education in any nation depends upon its Physical and Human resources. When we talk of human resources the most important thing that comes to our mind is the "Teacher" Education in any society does not depend so much on any other factor as on the teacher. Today the state of Higher Education in our country is worse. None of the Indian Universities feature in the world's top three hundred. Teacher education is also a part of this higher education and therefore something needs to be done in this regard as we are the ones who train future teachers. If this is the importance of a teacher, then we need

How to cite this article: Bhave, B. (2020). A Study of Problems of Teacher Educator in Self-Finance College of Education During COVID-19 Pandemic Situation. Educational Quest: An Int. J. Edu. Appl. Soc. Sci., 11(2): 59-62. 
to empower our teachers and teacher educators during COVID-19 pandemic situation.

\section{Research question of the study}

Research question of the present study was as: what are the problems of teacher educator of nongrantable college of education during COVID-19 pandemic situation in India?

Up to how many problems are faced by Teacher educator of Self-Finance college of Education during lockdown period and after unlock period. The need for the present study, therefore emerges - A study of Problems of teacher educators of Self-Finance college of Education during pandemic situation in Pune region. That's why Researcher have been thought to work on present study.

\section{Objectives of the study}

The study was taken up following objectives:

1. To study the Academic problems of Teacher educator of Self-Finance college of Education during COVID-19 Pandemic situation.

2. To study the Financial problems of Teacher educator of Self-Finance college of Education during COVID-19 Pandemic situation.

3. To study of problems regarding admission procedure of Self-Finance college of Education during COVID-19 Pandemic situation.

4. To suggest expected changes in Teacher Education.

\section{Population and Sample}

Populations of the present study were Teacher educator of self-finance College of Education. Purposively we selected 100 Asst. Professor as sample.

\section{Research Method}

For present study, survey type research method has been used.

\section{Tool And Data Collection}

5-point Rating Scale (RS) developed by investigators themselves have been used. In which twenty sentences were given in one section respectively. If they agree then they must only mark. Data were collected from sample by 5-point Rating Scale. The researcher sent the 5-point Rating Scale on google quiz to the professor and principals of the college affiliated to Savitribai Phule Pune University through WhatsApp.

\begin{tabular}{|c|c|c|c|c|}
\hline \multicolumn{5}{|c|}{ Frequency } \\
\hline $\begin{array}{c}\text { Strongly } \\
\text { Agree }\end{array}$ & Agree & $\begin{array}{c}\text { Neither } \\
\text { Agree nor } \\
\text { Disagree }\end{array}$ & Disagree & $\begin{array}{l}\text { Strongly } \\
\text { Disagree }\end{array}$ \\
\hline
\end{tabular}

\section{Technique Used for Analysis of the Data}

The first 100 respondents to the Google quiz were selected for statistical analysis. Data were analyzed by the statistical technique frequency and percentage.

\section{Analysis and Interpretation of the Data}

For all the problems of Rating scale frequency distribution have been prepared for analysis of data gating from sample. Which is find out the percentage with reference in Table 1.

\section{Observation \& Findings}

Following are some of the Problems of Teacher Educator of Self-Finance College of Educations During COVID-19 Pandemic Situation:

1. Less and irregular salary is main problems in self-finance college.

2. There is no security in service provide through management during pandemic situation

3. Deficiency of infrastructure and Online teaching facility is main problem for teaching in pandemic situation.

4. There were difficulties in Internal Assessment process.

5. There were difficulties in online teaching such as network problem, Lack of ICT tools etc.

6. Due to Lockdown, self-finance college Could Not Attempt Admission Process at College Level, Efforts Were Not Made for The Admission Process at College Level.

7. The College Did Not Collect Tuition Fees Due to Lockdown.

8. There were difficulties in Taking University Exams During COVID-19 Pandemic Situation.

9. The corona pandemic caused stress or tension among all teacher educators of self-finance B.Ed. College. 
Table 1: Rating scale on Problems of Teacher Educator of Self-Finance College of Educations During COVID-19 Pandemic Situation

\begin{tabular}{|c|c|c|c|c|c|c|}
\hline \multirow{2}{*}{$\begin{array}{l}\text { S1. } \\
\text { No. }\end{array}$} & \multirow[b]{2}{*}{ Problems } & \multicolumn{5}{|c|}{ Frequency } \\
\hline & & $\begin{array}{l}\text { Strongly } \\
\text { Agree }\end{array}$ & Agree & $\begin{array}{l}\text { Neither Agree } \\
\text { nor Disagree }\end{array}$ & Disagree & $\begin{array}{l}\text { Strongly } \\
\text { Disagree }\end{array}$ \\
\hline 1 & Get Less Salary during lockdown period & $(46) 46 \%$ & (26) $26 \%$ & (13)13\% & $(11) 11 \%$ & (4) $4 \%$ \\
\hline 2 & Paid Salary Irregularly after lockdown & $(37) 37 \%$ & $(32) 32 \%$ & $(11) 11 \%$ & $(13) 13 \%$ & (7) $7 \%$ \\
\hline 3 & There Is No Security of Service & $(40) 40 \%$ & (32) $32 \%$ & (11) $11 \%$ & $(10) 10 \%$ & (7) $7 \%$ \\
\hline 4 & $\begin{array}{l}\text { Students Did Not Submit Internal Assessment } \\
\text { Work Files, Journals During Lockdown Period }\end{array}$ & (13)13\% & (33)33\% & (13)13\% & (31)31\% & (10)10\% \\
\hline 5 & $\begin{array}{l}\text { Classroom Teaching Cannot Be Done During } \\
\text { Lockdown Period }\end{array}$ & $(36) 36 \%$ & $(41) 41 \%$ & (5) $5 \%$ & $(15) 15 \%$ & (3) $3 \%$ \\
\hline 6 & $\begin{array}{l}\text { Deficiency of Infrastructure Facilities for Online } \\
\text { Classes }\end{array}$ & $(23) 23 \%$ & (41) $41 \%$ & $(10) 10 \%$ & $(23) 23 \%$ & (3) $3 \%$ \\
\hline 7 & $\begin{array}{l}\text { Barriers Came in Online Teaching Learning } \\
\text { Process }\end{array}$ & $(11) 11 \%$ & $(67) 67 \%$ & $(12) 12 \%$ & (5) $5 \%$ & (5) $5 \%$ \\
\hline 8 & $\begin{array}{l}\text { It Became Difficult to Check the PDF Files } \\
\text { Submitted by Students }\end{array}$ & (8) $8 \%$ & $(50) 50 \%$ & $(18) 18 \%$ & $(16) 16 \%$ & (8) $8 \%$ \\
\hline 9 & $\begin{array}{l}\text { Due to Lockdown, Could Not Attempt Admission } \\
\text { Process at College Level }\end{array}$ & (21) $21 \%$ & $(39) 39 \%$ & $(20) 20 \%$ & $(18) 18 \%$ & (2) $2 \%$ \\
\hline 10 & $\begin{array}{l}\text { Due to Lockdown, Efforts Were Not Made for The } \\
\text { Admission Process at College Level }\end{array}$ & $(26) 26 \%$ & (36) $36 \%$ & $(20) 20 \%$ & $(13) 13 \%$ & (5) $5 \%$ \\
\hline 11 & $\begin{array}{l}\text { The financial crisis of the parents affected the } \\
\text { B.Ed. admission process }\end{array}$ & $(23) 23 \%$ & $(65) 65 \%$ & $(10) 10 \%$ & (2) $2 \%$ & (0) $0 \%$ \\
\hline 12 & $\begin{array}{l}\text { The College Did Not Collect Tuition Fees Due to } \\
\text { Lockdown }\end{array}$ & $(13) 13 \%$ & $(51) 51 \%$ & (20)20\% & (13) $13 \%$ & (3) $3 \%$ \\
\hline 13 & $\begin{array}{l}\text { Impossible to Take University Exams During } \\
\text { COVID-19 Pandemic Situation }\end{array}$ & $(33) 33 \%$ & $(49) 49 \%$ & (8) $8 \%$ & (5) $5 \%$ & (5) $5 \%$ \\
\hline 14 & Stress Increase During Lockdown & $(46) 46 \%$ & (28) $28 \%$ & (18)18\% & (5) $5 \%$ & (3) $3 \%$ \\
\hline 15 & Medical Facility, Medical Allowance Is Not Be Got & $(51) 51 \%$ & $(41) 41 \%$ & (5) $5 \%$ & (3) $3 \%$ & (0) $0 \%$ \\
\hline 16 & $\begin{array}{l}\text { Fear of Late Start New Academic Year Due to } \\
\text { COVID-19 Pandemic Situation }\end{array}$ & (39)39\% & (54) $54 \%$ & (3) $3 \%$ & (4) $4 \%$ & (0) $0 \%$ \\
\hline 17 & $\begin{array}{l}\text { Due to Lockdown, Expected Changes Regarding } \\
\text { Curriculum }\end{array}$ & $(28) 28 \%$ & $(64) 64 \%$ & (8) $8 \%$ & (0) $0 \%$ & (0) $0 \%$ \\
\hline 18 & $\begin{array}{l}\text { Due to Lockdown, Expected Changes in Teaching } \\
\text { Learning Process }\end{array}$ & (26) $26 \%$ & $(59) 59 \%$ & $(10) 10 \%$ & (5) $5 \%$ & (0) $0 \%$ \\
\hline 19 & $\begin{array}{l}\text { Online teaching will develop good interaction } \\
\text { between student and teacher }\end{array}$ & (13)13\% & (34)34\% & (13)13\% & $(37) 37 \%$ & (3) $3 \%$ \\
\hline 20 & COVID-19 Pandemic led to negativity in thought & $(22) 22 \%$ & $(44) 44 \%$ & (16)16\% & $(16) 16 \%$ & (3) $3 \%$ \\
\hline
\end{tabular}

Note: The numbers in brackets indicates the number of respondents while the number of outside the brackets indicates the percentage of response.

10. Teacher educators did not get medical allowances, medical facilities during the COVID-19 pandemic situation.

11. The corona pandemic has made it difficult for the new academic year to begin.

12. Due to COVID Pandemic situation expected to change the curriculum, teaching learning methodology and assessment process.

13. Online teaching does not interact students properly.
14. The lockdown create negativity in students and teachers.

15. More than ninety percent teacher education institutions are in the private and selffinancing sectors. These institutions exist as business centers for making profit. And the profit comes out of low overhead cost achieved out of low salary expenses of teacher educators who work on temporary basis or contract basis, with low salary 
without any benefits like pension, medical or maternity.

\section{Suggestions regarding problems}

1. Management should try to solve the Financial problems of Teacher educator and followed the rules and regulations of University.

2. Management should follow the rules and regulations of Government of Maharashtra, UGC and University.

3. UGC, NCTE, Admission Regulatory Authority of Maharashtra and State Government must reform rules and regulations for admission process of B.Ed., colleges and its implementation.

4. The course duration must not be time bound; it must not be rigid. In fact, if we desire our product to be efficient, the course must be competency based.

5. $25 \%$ curriculum must be online and need based. If online syllabus is to be framed, then there should be flexibility \& freedom to frame the online syllabus with reference to local needs, situation and global issues (Think globally work locally).

6. Regular updating \& upgrading of syllabus is necessary considering the global trends \& innovations in education \& technology.

7. Self-finance Teacher Education Institute must provide enough freedom, opportunities and motivation to the trainees for creation, experimentation during pandemic situation.
8. Management will motivate new thoughts, new ideas, new techniques, new knowledge \& theories also.

9. Expected Changes in Teaching Learning Process is necessary due to pandemic situation. This is the dimension of Teacher Education Institute which needs to be changed thoroughly.

10. The government, UGC, and University take appropriate decision regarding the examination during the pandemic situation.

\section{CONCLUSION}

Researcher observe the present teacher education institute is quite disappointing to face corona pandemic. Most of the Teacher educator of selffinance B.Ed. Colleges have faced get less salary, there is no security of service, workload tension because of lockdown.

\section{REFERENCES}

Best, W.B., Kahn, J.V. (10 ${ }^{\text {th }}$ Edition), Research in Education, New JERSEY, Pearson Prentice Hall.

Good, W.J. and Hall, P.K. 1992. Methods in Social Research, New York, MC Gran Hill Publication

Mhaske, T.A. 1988, Educational Statistical, Pune, Pradnya Publication.

http://mygov.in

https://www.ncte-india.org

www.unipune.ac.in

www.ugc.ac.in

https://www.who.int 